ADDIN, Vol. 10, No. 1, Februari 2016

\title{
PENGEMBANGAN NASIONALISME KEAGAMAAN SEBAGAI STRATEGI PENANGANAN POTENSI RADIKALISME ISLAM TRANSNASIONAL
}

\section{Muh. Khamdan}

Kementerian Hukum dan HAM Jakarta, Indonesia

khamdanwi@gmail.com

\begin{abstract}
Abstrak
Tulisan ini membuktikan bahwa penanggulangan potensi radikalisme agama dapat berjalan baik melalui pengembangan gerakan dan wacana yang berbasiskan nasionalisme keagamaan. Kekerasan atas nama agama oleh gerakan Islam transnasional tumbuh seiring berkembangnya kebebasan berekspresi di Indonesia, yang berusaha untuk mengganti dasar negara Pancasila. Tulisan ini menggunakan pendekatan teori konflik dan teori identitas sosial dalam menganalisis potensi radikalisme di masyarakat.
\end{abstract}

Kata Kunci: Radikalisme, Nasionalisme Keagamaan, Pancasila, Islam Transnasional.

\section{Abstract}

THE RELIGIOUS NATIONALISM DEVELOPMENT AS A TREATMENT STRATEGY OF THE TRANSNATIONAL ISLAMIC RADICALISM POTENTIAL: This paper proves that the reduction of the religious radicalism can run either through the development of movement and discourse based on the religious nationalism. The violence in the name of religion by 
Muh. Khamdan

transnational Islamic movement developed along with the development of the expression freedom in Indonesia, which seeks to replace the state ideology, Pancasila. This paper uses the approach of conflict theory and social identity theory in analyzing the potential radicalism in society.

Keyword: Radicalism, Religious Nationalism, Pancasila, Transnational Islam.

\section{A. Pendahuluan}

Radikalisme sebagai suatu faham tidak selalu ditandai dengan aksi-aksi kekerasan, namun dapat juga sebatas pemikiran dan ideologi yang tidak menggunakan cara-cara kekerasan dalam melaksanakan pemikiran tersebut. Potensi radikalisme yang ditentukan oleh persepsi individu tentu tidak hanya dipengaruhi suatu landasan ideologi tertentu, namun dapat juga dipengaruhi oleh beragam faktor lain dalam isu global, regional, maupun lokalitas.Aksi terorisme yang berlangsung di Indonesia misalnya, diawali adanya fanatisme ideologi sehingga menganggap yang lain salah dan berujung dengan penggunaan senjata atau aksi pengeboman.

Ideologi keagamaan sering menjadi motivasi sekaligus dorongan untuk membenarkan aksi kekerasan yang dilakukan. Penguatan kekerasan atas nama agama dianggap sebagai bentuk perjuangan keyakinan yang sangat mendasar dan wujud beragama secara kaffah. Hal demikian melahirkan kelompok masyarakat beragama yang lebih mengutamakan doktrin agama daripada toleransi yang berdasar cinta dan penghormatan hak asasi manusia. ${ }^{1}$ Ekspresi keberagamaan tersebut berkembang seiring dengan adanya muatan-muatan politik tertentu berupa pendirian negara Islam sebagai pengaruh gerakan transnasional yang tidak memiliki hubungan kesadaran terhadap kearifan lokal masyarakat.

Agama seringkali digunakan sebagai faktor legitimasi atau untuk menutupi konflik yang sesungguhnya. ${ }^{2}$ Aspek teologis

${ }^{1}$ Machasin, "Fundamentalisme dan Terorisme", dalam A. Maftuh Abegebriel, dkk (Ed)., Negara Tuhan: The Thematic Encyclopedia (Yogyakarta: Pustaka Pelajar, 2003), hlm. 121-127.

${ }^{2}$ Muh. Khamdan, Bina Damai Terorisme (Kudus: Parist, 2015), hlm. 40. 
atau agama dapat mempengaruhi munculnya radikalisme karena memahami agama dalam dua kutub yang berseberangan, yaitu merasa lebih benar atau lebih berhak untuk masuk surga serta adanya dendam sejarah dalam setiap perkembangan agama. ${ }^{3} \mathrm{Al}-$ Jabiri menegaskan bahwa radikalisme tidak lebih dari sekadar fenomena yang muncul dari persoalan sosial politik, kemudian dikemas dengan isu agama. ${ }^{4}$

Faktor diluar agama seperti krisis multidimensi yang berakibat pada perasaan terdiskriminasi melahirkan sikap saling curiga di tengah kelompok masyarakat. Pengakuan Ali Imron dalam peristiwa bom Bali I setidaknya menggambarkan latar belakang aksi pengeboman. Alasan ketidakpuasan terhadap pemerintah yang tidak berdasarkan syari'at Islam dan tidak adanya imämah menjadi dasar utama sejalan dengan fatwa Osama bin Ladin tentang pembolehan membunuh warga negara Amerika dan sekutunya di manapun. Faktor lain yang mendorong pemilihan lokasi pengeboman di Bali adalah tingkat kerusakan moralitas dan akidah masyarakat melalui pariwisata, melindungi umat Islam, dan pembalasan terhadap kafir yang memerangi kaum Muslim. ${ }^{5} \mathrm{Fatwa}$ Osama bin Ladin merupakan salah satu bukti adanya pengaruh gerakan transnasional yang berkembang menjadi gerakan radikal atas nama agama di Indonesia.

Seseorang atau kelompok yang melakukan tindakan karena dipengaruhi adanya sumber-sumber radikalisme tidak memandang bahwa aksinya tersebut sebagai sebuah kejahatan, tetapi muncul rasa kebanggaannya karena merasa telah menjadi pasukan yang memperjuangkan kebenaran apa yang diyakininya. ${ }^{6}$ Kelompokkelompok pejuang radikal yang kemudian berkembang menjadi

${ }^{3}$ Mark Jurgensmayer, Terror in the Mind of God: The Global Rise of Religious Violence (California: University of California Press, 2001), 14-15; James M. Lutz dan Brenda J. Luts, Global Terrorism (London: Routledge, 2004), 74-78.

${ }^{4}$ Muhammad 'Abid al-Jābiri, Qadaya al-Fiker al-'Aräbi: al-Mas-alah al-Thaqäfiyyah (Beirut: Markaz Dirâsah al-Wahidah al-'Arābiyyah, 1994), hlm. 134-135.

${ }^{5}$ Ali Imron, Ali Imron Sang Pengebom, Cet. 1 (Jakarta: Republika, 2007), 41-71; Kumar Ramakrishna, "Delegitimizing Global Jihadi Ideology in Southeast Asia", Contemporary Southeast Asia, Vol. 27, No. 3 (Desember 2005), hlm. 343-369.

${ }^{6}$ Imam Samudra, Aku Melawan Terorisme (Solo: al-Jazera, 2004), 114-115; Asep Adisaputra, Imam Samudra Berjihad, Cet. 1 (Jakarta: Grafika Indah, 2006),hlm. 62-69; 
gerakan transnasional seringkali menggunakan simbol-simbol militer dalam organisasi gerakannya, ${ }^{7}$ seperti Irish of Republican Army (IRA) di Irlandia, Euskadi Ta Askatasuna (ETA) di Spanyol, Hizbullah di Libanon, Harakat al-Muqawwama al-Islamiyyah (Hamas) di Palestina, Front Islamique du Salut(FIS) di Aljazair, Fuerzas Armadas Revolucionarias de Colombia (FARC) di Kolombia, The Moro National Liberation Front (MNLF) dan Abu Sayyaf's Group (ASG) di Filipina, Al-Qaeda dan Taliban di Afghanistan.

Gerakan Islam Transnasional merupakan gerakan yang kegiatannya melewati batas teritorial negara bangsa. Gerakan tersebut memiliki beragam varian tujuan dan garis perjuangan sesuai dengan sosial sejarah yang melatarbelakangi di negara-negara pendiriannya. Gerakan Pan-Islamisme dan Ikhwanul Muslimin di Mesir, Hizbut'Tahrir di Libanon, Jama'ah Tabligh di India dan gerakan-gerakan Islam lainnya terinspirasi oleh perlawanan kaum lemah dan kolonialisme.Perjuangan gerakan Islam transnasional seringkali diiringi adanya proses mengkritik dan menyalahkan kalangan yang berbeda dalam praktik beragama. Kebudayaan yang dianggap bukan dari Islam maka menjadi salah dan harus dijauhi dalam perlawanan pemikiran (ghazw al-fikr). Potensi kehidupan keberagamaan yang membentuk pola hitam putih atau salah benar mulai mengalami masa pertumbuhan bersamaan dengan iklim demokrasi yang menjamin kebebasan.

Pemerintah telah membangun hubungan kerjasama dengan para ulama melalui berbagai pendekatan untuk mengeliminir ideologi radikal yang diimpor dari luar Indonesia. Pendekatan dengan melibatkan peran para ulama untuk mengkampanyekan nasionalisme keagamaan dirasa efektif untuk mengidentifikasi potensi radikalisme yang berkembang di masyarakat luas. Langkah penyadaran nasionalisme dapat membangun imunitas pada diri masyarakat terhadap pemahaman dan gerakan yang berupaya menyerang kedaulatan nasional.

\footnotetext{
Wawan H. Purwanto, Terorisme Ancaman Tiada Akbir: Bahaya dan Strategi Pemberantasan di Indonesia, Cet. II (Jakarta: Grafindo Khazanah Ilmu, 2004), hlm. 53-55

7 Anisseh Van Engeland dan Rachael M. Rudolph, From Terrorism to Politics (Ethics and Global Politics) (Burlington: Ashgate Publishing Company, 1988).
} 


\section{B. Pembahasan}

\section{Gerakan Radikal Transnasional di Indonesia}

Organisasi gerakan radikal membangun jaringan internasional yang bersifat transnasional karena kelompokkelompok tersebut memiliki kepemimpinan bersifat global, bekerja secara jaringan lintas negara dan benua, serta mengusung cita-cita yang sama untuk menegakkan kembali kepemimpinan Islam yang ideal dalam bentuk khilafah atau negara Islam. Beberapa hal yang melatarbelakangi adalah kenyataan atas penderitaan umat Islam di berbagai negara akibat kolonialisme Barat terhadap negara-negara muslim maupun negara dengan penduduk mayoritas muslim. Jamaluddin al-Afghany misalnya membangkitkan patriotisme atas dasar solidaritas agama yang disebut dengan Pan Islamisme. ${ }^{8}$ Gerakan Islam yang bersifat transnasional memahami Islam secara monolitik dan menolak varian-varian Islam lokal karena dianggap sudah tercemar sehingga perlu dimurnikan kembali. ${ }^{9}$

Sejalan dengan majunya hubungan internasional yang terbangun antara pribumi Nusantara dengan negara-negara lain, pertukaran tokoh baik sebagai duta kerajaan maupun kalangan terdidik untuk belajar dan mengajar merupakan fakta yang tidak bisa dikesampingkan. Hubungan tersebut memunculkan genealogi intelektual yang kompleks, dan lebih menguat oleh ikatan spiritual tarekat sufi berupa guru atau murshid dan murid..$^{10}$ Perkembangan masyarakat muslim disertai adanya perintah haji dalam rukun Islam, mempengaruhi banyaknya muslim Indonesia pergi ke Makkah dan mulai berinteraksi dengan ajaran Wahhäbiyah yang menginginkan pemurnian Islam tanpa bermazhab atau tanpa adopsi budaya yang cenderung menjadi bid'ah, tahayul, dan khurafat.

${ }^{8}$ Ahmad Mansur Suryanegara, Api Sejarah (Bandung: Grafindo Media Pratama, 2013), hlm. 251.

${ }^{9}$ Abdurrahman Wahid (Ed.), Ilusi Negara Islam: Ekspansi Gerakan Islam Transnasional di Indonesia (Jakarta: Gerakan Bhineka Tunggal Ika, The Wahid Institute dan Maarif Institute, 2009), hlm. 43.

${ }^{10}$ Andree Feillard, NU vis-à-vis Negara: Pencarian Isi, Bentuk, dan Makna (Yogyakarta: LKiS, 1995), hlm. 3; Azyumardi Azra, Jaringan Ulama Timur Tengah dan Kepulauan Nusantara Abad XV II dan XVIII, Cet. I (Bandung: Penerbit Mizan, 1994), hlm. 45. 
Muh. Khamdan

Pengaruh ideologi transnasional yang mengarah pada gerakan radikalisme agama di Indonesia dimulai pada kelompok Padri di Minangkabau. Haji Miskin dari Lu(h)ak Agam, Haji Abdur Rahman dari Piobang Limah Puluh Kota, dan Haji Muhammad Arief dari Sumanik, Batusangkar sekembalinya pulang dari Makkah pada masa antara 1803 dan 1804, membentuk kelompok Padri untuk melakukan pemurnian keberagamaan masyarakat Minangkabau dari kontaminasi budaya dan adat yang dianggap tidak sesuai dengan ajaran al-Quran. ${ }^{11}$ Haji Miskin bersama tokohtokoh kelompok Padri mengerahkan kekuatan bersenjata dalam upaya pemurnian agama sebagaimana dilakukan kaum Wahabi di Arab yang berkolaborasi dengan pasukan militer Al-Sa'ūd sejak 1744 untuk menguasai semenanjung Arabia. ${ }^{12}$ Gerakan perubahan yang dilakukan Haji Miskin dan tokoh Padri mendapat tantangan keras dari guru-guru tarekat Shattariyah karena gerakan yang dilakukan cenderung memilih langkah kekerasan dan pengkafiran atau penyesatan atas keyakinan orang lain.

Gerakan Padri mudah menggelari ulama lain sebagai orang sesat sebagaimana Tuanku Nan Renceh memusuhi Tuanku Nan Tuo, gurunya sendiri, dan memusuhi orang-orang yang tidak berpandangan sama. Tuanku Nan Renceh juga menghukum mati bibinya sendiri yang sudah lanjut usia dan tidak membolehkan menguburkan jasadnya tetapi dibuang ke hutan karena mengunyah sirih yang diharamkan kalangan Wahabi. ${ }^{13}$ Kekerasan yang dilakukan kaum Padri misalnya, berupa penyerangan dan pembunuhan terhadap keluarga kerajaan Pagaruyung, Tanah Datar. Kerajaan yang telah memeluk Islam sejak abad ke-16 ini diserang kaum Padri pada 1809. Tuanku Lelo sebagai salah seorang pemuka kelompok Padri menyebut keluarga raja seperti Tuanku Rajo Naro, Tuanku di Talang, tidak menjalankan Islam secara

${ }^{11}$ Amir Sjarifudin TJ, Minangkabau Dari Dinasti Iskandar Zulkarnain Sampai Imam Bonjol (Jakarta: Gria Media Prima, 2014), hlm. 514.

${ }^{12}$ Khaled Abou el-Fadl, Selamatkan Islam dari Muslim Puritan (Jakarta: Serambi, 2005), hlm. 80-81.

${ }^{13}$ Mangaraja Onggang Parlindungan, Pongkinangolngolan Sinambela Gelar Tuanku Rao: Teror Agama Islam Mąhab Hambali di Tanah Batak. 1816-1833, (Yogyakarta: LKiS, 2007), hlm. 132. 
benar, dan dianggap kafir. Tragedi berdarah terjadi pada 1815, gerakan Padri di bawah pimpinan Tuanku Lintau membunuh keluarga kerajaan Pagaruyung sehingga menyulut Perang Padri secara masal. ${ }^{14}$

Gerakan pemurnian agama yang disertai kekerasan oleh kaum Padri untuk merubah sistem politik sekaligus tradisi keberagamaan masyarakat Minangkabau, dapat disebut sebagai kelompok salafisme fundamental ${ }^{15}$ yang revolusioner. Hal demikian berdasarkan pendekatan Grant Wardlaw dalam memahami aksi kekerasan yang dilakukan antara warga sipil dengan negara. ${ }^{16}$ Berdasarkan pendekatan Angel Rabasa tentang sumber radikalisme Islam, gerakan Padri dipengaruhi adanya pemusatan otoritas keagamaan. ${ }^{17}$

Olivier Roy menjelaskan bahwa fundamentalisme agama seringkali berubah menjadi aksi radikal untuk mereformasi masyarakat melalui politik kekuasaan. ${ }^{18}$ Langkah demikian mengalami penafsiran ulang sebagai gerakan radikal berupa perlawanan di berbagai daerah terhadap Kerajaan Protestan Belanda yang menjajah Indonesia, yaitu Perang Lampung (18321833) dipimpin Imba Koesoema, Perang Banjarmasin (18591905) dipimpin Pangeran Antasari, Perang Batak (1872-1907) dipimpin Si Singamangaradja XII, Perang Aceh (1873-1914) dipimpin Teuku Umar bersama Cut Nyak Din, dan Perang Jawa di berbagai tempat. ${ }^{19}$

Perubahan politik Kesultanan Turki Usmani menjadi Republik Sekuler Turki oleh Mustafa Kemal Atartuk pada 3

${ }^{14}$ Adrianus Khatib, "Kaum Padri dan Pemikiran Keagamaan di Minangkabau”, Disertasi, Tidak Diterbitkan, (Jakarta: Pascasarjana IAIN Syarif Hidayatullah, 1991), hlm. 269.

${ }^{15}$ Nazih Ayubi, Political Islam: Religion and Politics in the Arab World (London and New York: Routledge, 1991), hlm. 67.

${ }^{16}$ Grant Wardlaw, Political Terrorism (New York: Cambridge University Press, 1986), hlm. 14-15.

${ }^{17}$ Angel M. Rabasa, The Muslim World After 9/11 (Arlington: The RAND Corporation, 2004), hlm. 36.

${ }^{18}$ Olivier Roy, Genealogi Islam Radikal (Yogyakarta: Genta Press, 2005), hlm. 13.

${ }^{19}$ Ahmad Mansur Suryanegara, API Sejarah, cet. 6 (Bandung: Grafindo Media Pratama, 2013), hlm. 234-270.

ADDIN, Vol. 10, No. 1, Februari 2016 
Maret 1924 berdampak menurunnya pengaruh gerakan PanIslamisme. Keadaan tersebut didukung dengan jatuhnya Raja Husein dan Raja Ali yang menganut Islam Ahli Sunnah Wal Jamaah sebagai raja Hijaz oleh pemberontakan keluarga Sa'ud dengan menobatkan Muhammad bin Abdul Aziz sebagai raja yang didukung Kerajaan Anglikan Inggris. ${ }^{20}$ Dominansi gerakan wahabi menguasai Makkah menjadikan jejaring intelektual ulama dan santri dari Indonesia mengalami pertentangan karena berbeda secara ideologi politik keagamaan sebagaimana pembentukan Komite Hijaz pada 31 Januari 1926 oleh ulama Ahlussunnah Wal Jamaah di Indonesia yang kemudian menjadi organisasi bernama Nahdlatul Ulama. ${ }^{21}$ Komite Hijaz yang dibentuk KH. Abdul Wahab Chasbullah bertujuan untuk meminta Raja Saud memberikan kebebasan menjalankan ajaran empat mazhab fikih di Makkah dan Madinah, serta tidak membongkar makam Nabi dan tempat-tempat bersejarah dalam Islam.

Penolakan sistem pemerintahan Indonesia setelah kemerdekaan dilakukan oleh gerakan sipil bersenjata Darul Islam/Tentara Islam Indonesia (DI/TII). Gerakan yang dipimpin Sekarmadji Maridjan Kartosoewiryo ingin membentuk negara Islam dengan memproklamasikan Negara Islam Indonesia (NII) pada 7 Agustus 1949 di Desa Cisampah, Ciawiligar, Tasikmalaya. Pemberontakan NII berakhir setelah Kartosoewiryo ditangkap pada 3 Juni 1962 melalui operasi pagar betis yang menyekat wilayah komunikasi gerilyawan dengan masyarakat. Kematian Kartosoewiryo tidak menyurutkan keberlangsungan gerakan dari pentolan eks-Darul Islam atau Tentara Islam Indonesia (DI/TII) untuk tetap memperjuangkan Negara Islam Indonesia.

Banyak mantan anggota DI yang kemudian mendukung Golkar setelah dilakukan pendekatan politik oleh pemerintah, namun banyak juga yang menolak sehingga melahirkan dua faksi. DI Fillah sebagai faksi yang menolak melakukan jihad

${ }^{20}$ Abdul Aziz, Chiefdom Madinah: Salah Paham Negara Islam (Jakarta: Pustaka Alvabet, 2011), xviii; Zuhairi Misrawi, Madinah: Kota Suci, Piagam Madinah, dan Teladan Muhammad SAW (Jakarta: Penerbit Buku Kompas, 2009), hlm. 270-271.

${ }^{21}$ Ali Maschan Moesa, Nasionalisme Kiai: Konstruksi Sosial Berbasis Agama (Jogjakarta: LKiS, 2007), hlm. 131. 
perlawanan bersenjata dipimpin oleh Djaja Sudjadi, Adah Djaelani Tirtapraja, Ateng Djaelani, dan Danu Muhammad Hasan. Pada faksi DI Fisabilillah yang dipimpin oleh Ahmad Sobari, tetap melanjutkan semangat Kartosoewiryo untuk mendirikan Negara Islam Indonesia (NII), sehingga mengarah pada aksi radikal dan kemudian hari disebut terorisme. Kegagalan NII untuk mendirikan Darul Islam mengalami bentuk baru dalam organisasi yang memperbolehkan melakukan perlawanan senjata, yaitu Jama'ah Islamiyah (JI). ${ }^{22}$ Gerakan perlawanan ini memanfaatkan situasi kebebasan demokrasi di Indonesia, sehingga tokohtokoh eks DI/TII ataupun aktivis JI yang berasal dari Indonesia membangun jejaring kekuatan baru.

Gerakan reformasi Islam yang semula menyatakan Islam klasik sebagai penyebab kemunduran Islam, beralih sasaran untuk merekonstruksi ulang ideologi politik modern. Gerakan tersebut berjalan seiring berkembangnya ideologi jihad kontemporer yang dipengaruhi pemikiran Sayyid Qutb. ${ }^{23}$ Pemikiran Qutb sebagaimana dikutip As'ad, membagi masyarakat atas 2 (dua) kelompok, yaitu masyarakatjahiliyahyang melakukan pengingkaran hukum-hukum Allah dan masyarakat Islam yang menerapkan hukum Allah (al-ḥakimiyyah lilläh). Kemunduran yang dihadapi umat Islam di berbagai negara, mulai dai kemunduran ekonomi, pemerintahan, dan moralitas masyarakat seakan mendapatkan jawaban karena budaya jabiliyah sebagai akibat tidak diterapkannya hukum Allah berupa hukum Islam secara utuh.

Pemikiran tersebutberimplikasi pada penegasian semua yang bukan Allah dan bukan dari Allah sesat, musyrik, kafir, dan zalim. Islam menurut kalangan fundamentalisme adalah kesatuan antara agama, dunia, dan negara (dìn, dunyā, dawlah), sehingga perlu adanya pendirian negara Islam yang dipimpin oleh seorang khälifah untuk dapat berjalannya agama secara

\footnotetext{
${ }^{22}$ Rohan Gunaratna, Inside Al-Qaeda, Global Network of Terror (New York: Columbia University Press, 2002).

${ }^{23}$ As'ad Said Ali, Al-Qaeda: Tinjanan Sosial-Politik, Ideologi dan Sepak Terjangnya (Jakarta: LP3ES, 2014), hlm. 16-17.
} 
murni dan käffah. ${ }^{24}$ Gerakan ini dijalankan oleh Hizbut Tahrir yang dimotori Taqiyuddīn an-Nabhānī di Syria, Libanon, dan Yordania pada 1953, serta telah dinyatakan sebagai organisasi terlarang di negara asalnya berdiri tersebut. Embrio Hizbut Tahrir yang terlarang tersebut membangun kekuatan kembali di Indonesia dengan organisasi Hizbut Tahrir Indonesia (HTI).

Transformasi pemikiran Qutb menginspirasi Jamaah Al-Muslimin yang dipimpin Syukri Musthofa, Jamaah Jihad atau Tanzimul Jihad pimpinan Muhammad Abdul Aziz asySayqawi bersama Ismail Thanthawi, dan Jamaah Islamiyah yang diprakarsai Umar Abdurrahman, untuk melakukan aksi konkret menerapkan al-ḥakimiyyah lilläh untuk mengganti hukum kafir jahiliyah. ${ }^{25}$ Langkah konkret mengganti pemerintahan kafir merupakan keharusan dan memeranginya menjadi suatu kewajiban sebagaimana pemahaman atas Surat Al-Anfal Ayat 44. ${ }^{26}$ Perang terhadap pemerintahan kafir mencakup juga mengusir orang-orang kafir dari negeri Islam karena menjadi penyebab penghancuran agama Islam. ${ }^{27}$ Pendapat yang dikembangkan oleh Abdullah Azzam, ulama Yordania keturunan Palestina, ini dipengaruhi pengalaman jihad di Afganistan melawan Uni Soviet dan traumatik atas perang Palestina dengan Israel. Jihad menurut Azzam adalah satu-satunya cara untuk memperjuangkan dan menjadi kewajiban permanen yang bersifat fardhu 'ain karena Islam tegak dengan pedang dan lebih utama daripada kewajiban sholat, puasa, atau haji.

Perkembangan demokratisasi di Indonesia semakin memudahkan para aktivis Jamaah Islamiyah untuk melakukan aksi terornya, terlebih muncul fatwa dari Usamah bin Laden yang

${ }^{24}$ Taqiyuddīn an-Nabhānī, Daulah Islam, terj. Umar Faruq (Jakarta Selatan: HTI Press, 2009), 273.

${ }^{25} \mathrm{Abdul}$ Mun'im al-Hafni, Ensiklopedia Golongan, Kelompok, Aliran, Mą̧ab, Partai dan Gerakan Islam (Jakarta: Grafindo, 1999), hlm. 318.

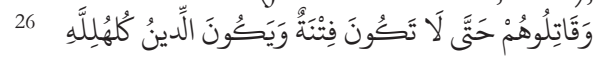

Dan perangilah mereka, supaya jangan ada fitnabdan supaya agama itu semata-mata untuk. Allah.

${ }^{27}$ Abdullah Azzam, Runtubnya Khilafah dan Upaya Menegakekannya (Solo: Pustaka Al-Haq, 2002), hlm. 158. 
memperbolehkan serangan kepada warga sipil, terutama warga Amerika Serikat sebagai aksi balasan (retaliation). ${ }^{28}$ Hubungan fatwa dengan kegiatan teror terwujud setelah muncul peledakan bom terhadap 15 gereja di beberapa daerah di Indonesia pada malam natal 2000. Operasi teror demikian jelas sangat terencana dan masuk dalam kategori operasi militer oleh jejaring Al-Qaeda dan Jama'ah Islamiyah di Indonesia.

Mobilisasi sel-sel gerakan radikal Indonesia dilakukan oleh Dulmatin dengan dukungan Abu Bakar Ba'asyir sebagai amir Jamaah Ansharut Tauhid (JAT) melalui pelatihan militer di Bukit Janto, Aceh Besar, pada Juli 2009. Para kader dari berbagai kelompok ikut bergabung, seperti JAT, kelompok Dulmatin, Ring Banten sebagai bagian dari faksi DI Jawa Barat, faksi DI Enceng Kurnia, Mujahidin KOMPAK, Tauhid wal Jihad, eks NII, Mujahidin Lampung, dan alumni konflik Poso. ${ }^{29}$ Polisi mampu mengungkap pelatihan terorisme lintas jaringan tersebut pada 22 Pebruari 2010, sehingga menyebabkan terpencar-pencarnya buronan aksi radikal terorisme ke seluruh Indonesia.

Sigit Qardhawi bersama kelompok Hisbah tertembak Densus 88 pada 15 Mei 2011, Abu Roban tertembak di Batang dengan kelompok teroris Mujahidin Indonesia Barat (MIB), Fadli Sadana tertangkap dalam perampokan Bank CIMB Medan, dan Santoso alias Abu Wardah dengan kelompok teroris Mujahidin Indonesia Timur (MIT). Kegagalan membangun pusat jaringan di Aceh, menjadikan pusat pelatihan berpindah ke Poso dengan munculnya jaringan terorisme MIT pimpinan Santoso dan Daeng Koro.

Kelompok Santoso dan Daeng Koro diindikasikan berpencar untuk menghindari operasi Camar yang dilakukan oleh aparat keamanan pada Pebruari-Maret 2015. Penyisiran aparat keamanan di Poso membuahkan hasil dengan tewasnya Daeng Koro di Pegunungan Sakina Jaya, Sulawesi Tengah, pada

\footnotetext{
${ }^{28}$ Christopher M. Blanchard, Al-Qaeda: Statements and Evolving Ideology (Congressional Research Service Report for Congress, 2005), hlm. 3.

${ }^{29}$ International Crisis Group, Bagaimana Kelompok Ekstrimis Membentuk Kelompok Baru (Jakarta: International Crisis Group, 2012).
} 
3 April 2015. Kelompok MIT telah mendeklarasikan diri sebagai pendukung kelompok Islamic State of Iraq and Sham(ISIS) pimpinan Abu Bakr al-Baghdadi, sehingga Santoso sebagai pemimpin yang tersisa menjadi yang paling dicari serta semakin terdesak.

ISIS sebagai organisasi teroris transnasional bertujuan untuk mendirikan Daulah Islamiyah dalam sistem khilafah. Pernyataan ikrar dukungan terhadap ISIS terjadi di berbagai wilayah indonesia, seperti yang dilakukan sekitar 50 warga Pekayon Jaya, Bekasi Selatan, atas pimpinan seorang anggota JAT yang bernama Syamsudin Uba. Militansi Islam di Indonesia sejak deklarasi NII dengan kekuatan militer DI/TII yang berjuang untuk mendirikan negara Islam, memiliki titik pertemuan dengan ideologi ISIS. Mutasi kelompok Islam radikal dan penyebaran sel jaringan terorisme membuat propaganda ideologi ISIS mudah menyebar di tengah masyarakat.

Simpatisan ISIS di Indonesia berasal dari gabungan beberapa kelompok radikalisme sebelumnya yaitu JI, JAT, MIT, dan MIB. Hal demikian dapat dibuktikan dengan adanya propaganda di situs youtube. Bahrumsyah alias Abu Muhammad Al-Indonesy melakukan propaganda menantang pemerintah Indonesia, TNI, dan Gerakan Pemuda Anshor NU. Keterlibatan JAT dalam mendukung ISIS dapat dilihat pada baiat yang dilakukan oleh 23 narapidana terorisme pimpinan Abu Bakar Ba'asyir di Lapas Pasir Putih, Nusakambangan. Warisan ideologi radikal transnasional tersebut dapat mempengaruhi kelanjutan perjuangan terorisme kendati berubah bentuk gerakan dan aksi.

\section{Pemahaman Tekstual Sebagai Titik Awal}

Penafsiran hermeneutik dianggap menodai kesucian agama sehingga ekspresi keberagamaan masyarakat menjadi tekstualis. Tampilan keberagamaan demikian mempengaruhi pemahaman radikalisme karena teks dalil tidak dilihat berdasarkan konteks kehidupan masyarakat tetapi sebagai indikator benar dan salah. Pemahaman tekstual gerakan Islam radikal yang bersifat transnasional biasanya dikaitkan dengan dalil tidak ada hukum kecuali dari Allah (lā ḥukma illa lillăh), dan barangsiapa yang 
menggunakan hukum selain dari Allah adalah kafir. ${ }^{30}$ Dalil ini tentu menjadi pondasi pemikiran bahwa Islam adalah agama yang sudah sangat sempurna dan paripurna untuk mengatur segala aspek kehidupan, ${ }^{31}$ termasuk politik. Pandangan demikian sebagaimana menjadi garis ideologi Hasan al-Banna, Sayyid Quthb, Rashid Ridha, Taqiyudin an-Nabhani, dan al-Mawdudi.

Dalam sejarah pemikiran Islam awal, dalil kekafiran tersebut telah digunakan oleh kelompok Khawarij untuk menghakimi Ali bin Abi Thalib, 'Amr bin Ash, dan Mu'awiyah bin Abi Sufyan, Abu Musa al-Asy'ari yang melakukan tabkim (perdamaian) dalam Perang Siffin pada 37 H / 657 M dengan mengangkat alQur'an di atas ujung tombak. ${ }^{32}$ Golongan yang menolak tabkim karena dianggap tidak sesuai dengan hukum Allah sehingga keluar dari barisan Ali dalam musyawarah perdamaian di Daumatul Jandal dengan mengkafirkan para sahabat senior ini, dipimpin oleh Abdullah Ibn Wahab Al-Rasyidi dengan jumlah 12.000 pasukan. $^{33}$

Perkembangan corak pemikiran kelompok khawarij dengan berbagai sekte-sekte di dalamnya setidaknya dapat difahami melalui identitas yang sama, yaitu membatasi dalil agama hanya pada al-Qur'an dan al-Hadits. Oleh karenanya, terjadi penolakan atas ijma' (kesepakatan para ulama) dan qiyass (analogi) yang keduanya sangat dekat dengan penggunaan akal atau logika dalam penentuan hukum yang tidak terdapat di dalam al-Qur'an dan alHadits terutama menyangkut urusan duniawi. ${ }^{34}$ Metodologi ta'wil (penafsiran terhadap dalil) dengan menggunakan akal atau logika dianggapnya hanya akan membuat agama tidak murni lagi karena

${ }^{30}$ Q.S. al-Ma'idah [5]: 44.

${ }^{31}$ Q.S. al-Ma'idah [5]: 3.

${ }^{32}$ Muhammad Abū Zahrah, Tārìkh al-Madhāhib al-Islāmiyah (Cairo: Dār el-Fikr al-'Arābi, tt), 99; Abī Ja'far Muhammad ibn Jarīr al-Ṭabarī, Târìkh al-Tabari: Tärikh al-Rasūl wa al-Muluk, juz III (Kairo: Dār al-Ma’ārif, 1963), hlm. 540-543.

${ }^{33}$ Harun Nasution, Theologi Islam, Sejarah Analisa dan Perbandingan (Jakarta: UI Press, 1991), hlm. 23; Azyumardi Azra, Pergolakan Politik Islam (Bandung: Mizan, 1999), hlm. 112-113; Philip K. Hitti, History of The Arabs (London: The Macmilan Press LTD, 1974), hlm. 181-183.

${ }^{34} \mathrm{Abu}$ Muhammad Ibn Hazm, al-Ị̣kām fì Ușül al-Aḥkeàm, Vol. 1 (Beirut: Dār al-Afaq al-Jadīdah, 1980), hlm. 27. 
terkontaminasi pendapat-pendapat manusia yang tidak memiliki wewenang menetapkan syari'at.

Purifikasi hukum Tuhan sebagaimana menjadi garis ideologi Ikhwanul Muslimin (IM) menganggap hukum hanya bersumber dari Islam, bukan bersumber dari agama-agama lain. Pandangan demikian yang telah memicu suburnya benih-benih fanatisme keberagamaan yang mengarah pada ekstrimisme. ${ }^{35}$ Hukum Tuhan dalam QS. Al-Maidah ayat 44 difahami sebagai hukum kelompok tertentu yang telah dikodifikasi, sebagaimana hukum yang telah dikodifikasi oleh ulama Syiah atau ulama Sunni. Konteks historis turunnya ayat tersebut berkaitan orang Yahudi yang dihukum cambuk dan dipanasi badannya karena melakukan perzinahan dan sudah berkeluarga. ${ }^{36} \mathrm{Hal}$ ini menjelaskan bahwa ayat tersebut tidak berkaitan dengan pendirian negara Islam atau sistem khilafah tetapi kewajiban bagi agama samawi untuk melaksanakan hukum dalam kitab sucinya sendiri.

Tabel 1. Dalil Kekerasan Atas Nama Agama ${ }^{37}$

No Dalil Pemahaman

1 Q.S. al-Ma’idah [5]: 44 Berhukum selain hukum Allah adalah kafir

\begin{tabular}{lll}
\hline 2 & Q.S. al-Ma'idah [5]:3 & $\begin{array}{l}\text { Islam sudah sempurna mengatur semua } \\
\text { bidang }\end{array}$ \\
\hline 3 & Q.S. al-Fath [48]: 29 & Bersikap keras terhadap orang-orang kafir \\
\hline 4 & Q.S. al-Ma'idah [5]: 5 & $\begin{array}{l}\text { Perintah untuk membunuh, menangkap, dan } \\
\text { mengintai orang-orang musyrikin }\end{array}$ \\
\hline 5 & Q.S. al-Baqarah [2]: 120 & $\begin{array}{l}\text { Yahudi dan Nasrani selalu memiliki rencana } \\
\text { untuk menyerang umat Muslim }\end{array}$ \\
\hline
\end{tabular}

Metode memahami pemahaman dalil secara tekstual dengan menolak pendekatan-pendekatan lainnya menjadikan kelompok ini cenderung bersifat eksklusif dan fanatik. Kelompok literalis ini tidak bersahabat dengan kelompok di luar bagiannya serta

${ }^{35}$ Zuhairi Misrawi, Al-Qur'an Kitab Toleransi Inklusivisme, Pluralisme, dan Multikulturalisme (Jakarta: Penerbit Fitrah, 2007), hlm. 401.

${ }^{36}$ Imām al-Wāḥidi, Asbāb al-Nuzūl (Kairo: Dār al-Ḥadīth, 2003), hlm. 150.

${ }^{37}$ Nasaruddin Umar, Deradikalisasi Pemahaman Al-Qur'an dan Hadis (Jakarta: Elex Media Komputindo, 2014), hlm. 83-232. 
selalu berfikir negatif dengan kelompok lain. Bersikap keras atas kekafiran bukanlah menyerang fisik orang kafir, tetapi pemahaman untuk melawan nilai-nilai kekafiran dalam konteks toleransi, yaitu ketidakadilan, dan kediktatoran dalam masyarakat.

\section{Nasionalisme vis a vis Agama}

Nasionalisme ulama dengan menerima Pancasila sebagai dasar negara Indonesia merupakan sikap tengah yang diambil untuk menjaga persatuan Indonesia, sekaligus menjaga keberlangsungan beragama. NU dan Muhammadiyah sebagai organisasi yang terdepan dalam pembelaan nasionalisme Indonesia tidak tertarik untuk melakukan formalisasi hukum Islam dalam kehidupan kebangsaan dan kenegaraan sebagaimana pemberlakuan hukum Islam dalam ruang publik, tata negara, dan administrasi negara, termasuk hukum privat keluarga seperti perkawinan, waris, dan perbankan. NU sendiri sebelum masa kemerdekaan melalui muktamar ke-11 pada 1936 di Banjarmasin mengukuhkan Indonesia sudah sebagai negara Islam karena masyarakatnya mayoritas beragama Islam dan tidak ada larangan menjalankannya kendati dipimpin oleh Kerajaan Protestan Belanda. ${ }^{38}$ Relasi agama dan negara oleh ulama-ulama NU dianggap dalam hubungan akomodatif dengan mempertahankan nasionalisme Indonesia tanpa membedakan agama, suku, dan golongan. Politik sebagai sumber radikalisme sebagaimana pendapat Angel Rabasa, diredam oleh ulama NU dengan fatwa penerimaan terhadap Pancasila sebagai dasar negara.

Pertarungan gagasan antara nasionalisme dan agama selalu mengarah pada 2 (dua) problem utama, yaitu relasi muslim versus non-muslim dan hukum Tuhan versus hukum manusia. Pondasi yang harus dibangun adalah kesadaran bahwa Islam sebagai agama kemanusiaan. Kateori teologis untuk dilakukan perubahan pemahaman terdiri atas relasi Islam dengan non-Islam, hukum Tuhan dalam agama-agama, Islam rahmatan lil 'älamin, serta paradigma jihad dan perang. ${ }^{39}$

${ }^{38}$ Jimmy Oentoro, Indonesia Satu, Indonesia Beda, Indonesia Bisa (Jakarta: Gramedia Pustaka Utama, 2010), hlm. 167.

${ }^{39}$ Materi Pembinaan Keagamaan di LP Cipinang, 2010-2011. 
Pemilihan ayat yang sangat populer bagi kalangan Islam radikal dalam hal hubungan antara Islam dengan agama lain adalah Q.S. al-Baqarah [2]: 120: "Orang-orang Yabudi dan Nasrani tidak akan senang kepada kamu bingga kamu mengikuti agama mereka. Katakanlah: "Sesunggubnya petunjuk. Allah itulah petunjuk (yang benar)". Dan sesunggubnya jike a kamu mengikuti kemanan mereka setelah pengetahuan datang kepadamu, maka Allah tidak lagi menjadi pelindung dan penolong bagimu.".

Terdapat 3 (tiga) problem atas ayat tersebut yang digunakan untuk memerangi atau mencurigai kalangan non-Islam. ${ }^{40}$ Pertama, munculnya persepsi bahwa orang di luar Islam terutama umat Kristen dan Yahudi sebagai musuh abadi, yang dikuatkan adanya beberapa ayat yang mengecam perilaku kaum Yahudi dan Kristen atas Nabi Muhammad beserta para pengikutnya. Kedua, hubungan permusuhan diberlakukan dalam jangka waktu yang tidak terbatas sehingga memandang semua orang Yahudi dan Kristen sebagai musuh. Ketiga, hilangnya perhatian terhadap ayat-ayat lain yang menyerukan aspek toleransi sehingga AlQur'an yang terdiri dari ribuan ayat seolah digeneralisir dalam ayat tertentu saja.

Pembinaan yang diberikan terkait penjelasan ayat tentang relasi Islam dan non-Islam adalah menyadarkan bahwa memahami ayat perlu terlebih dahulu memahami latar belakang sejarah penurunan ayat. Dalam Q.S. al-Baqarah [2]: 120, Imām al-Wāhịī menerangkan bahwa suatu saat orang Yahudi dan Kristen mengajukan gencatan senjata kepada Rasulullah. Pada saat Rasulullah hampir menerima gencatan senjata, Allah mengingatkan melalui ayat tersebut bahwa orang Yahudi dan Kristen selamanya tidak akan rela mengikuti gencatan senjata atau perjanjian damai dengan Islam. ${ }^{41}$ Latar belakang kedua berkaitan dengan permintaan orang Yahudi dan Kristen untuk tetap menghadapkan kiblat ke arah Masjid al-Aqsha, Jerussalem.

${ }^{40}$ Zuhairi Misrawi, Al-Qur'an Kitab Toleransi: Inklusivisme, Pluralisme, dan Multikulturalisme (Jakarta: Penerbit Fitrah, 2007), hlm. 383-384.

${ }^{41}$ Imām al-Wāhịī̄, Asbāb al-Nuqūul (Kairo: Dār al-Ḥadith, 2003), hlm. 39. 
Konteks sejarah dalam mewarnai lahirnya teks keagamaan tentu memiliki nuansa yang berbeda jika dihubungkan dalam ruang kerjasama di bidang pendidikan, ekonomi, politik, kebudayaan, dan lainnya. Hal demikian disebabkan karena ayat tersebut berkaitan dengan gencatan senjata dan pemindahan arah kiblat. Permusuhan terhadap Yahudi dan Nasrani yang digeneralisasikan untuk semua bidang maka akan berlawanan dengan ayat yang menyatakan pentingnya memahami keragaman suku, bangsa, dan agama.

Pemahaman yang mendasari gerakan keagamaan pada kewajiban menegakkan hukum Tuhan, sudah dilakukan oleh Wahabisme yang disponsori oleh Arab Saudi dengan melakukan institusionalisasi paham keagamaan. ${ }^{42}$ Imbasnya, hukum Tuhan dianggap sebagai hukum yang bersumber dari Islam saja dengan meniadakan agama lain. Hukum Islam juga mengalami pengerucutan sebagai hukum yang diturunkan kepada kelompok tertentu, misal hukum Islam yang dikodifikasi ulama Sunni maka dianggap bukan sebagai hukum Tuhan oleh kalangan Syiah. Kenyataan tersebut dapat dilihat dari apa yang pernah dipraktikkan kalangan Khawarij dengan menyatakan Ali bin Abu Tholib dan Muawiyah sebagai orang kafir.

Memperhatikan Q.S. al-Ma'idah [5]: 44 dan 47 dijelaskan adanya hukum yang diatur bukan hanya hukum Islam, tetapi juga hukum Tuhan di dalam Kitab Taurat dan Kitab Injil. Pandangan demikian yang sekiranya menjadikan 47 (empat puluh tujuh) narapidana terorisme LP Cipinang dari 58 (lima puluh delapan) orang, dan para mantan narapidana terorisme dapat menerima Pancasila sebagai sumber hukum di Indonesia karena konsep Pancasila diambil dari teks keagamaan Islam oleh para perumusnya.

${ }^{42}$ Khaled Abou el-Fadl, The Great Theft: Wrestling Islam from the Extremists (New York: harperSan Fransisco, 2005), hlm. 45-94. 
Muh. Khamdan

Tabel 2. Hubungan Dalil Islam dan Sila Pancasila ${ }^{43}$

\begin{tabular}{|c|c|c|}
\hline No & Sila Pancasila & Dalil Islam \\
\hline 1 & $\begin{array}{l}\text { Ketuhanan Yang Maha } \\
\text { Esa }\end{array}$ & $\begin{array}{l}\text { Dan Tuhanmu adalah Tuhan Yang Maha } \\
\text { Esa Q.S. al-Baqarah [2]: } 163\end{array}$ \\
\hline 2 & $\begin{array}{l}\text { Kemanusiaan yang adil } \\
\text { dan beradab }\end{array}$ & $\begin{array}{l}\text { Hai orang-orang yang beriman hendaklah } \\
\text { kamu jadi orang-orang yang selalu } \\
\text { menegak.kan (kebenaran) karena Allah, } \\
\text { menjadi sakesi dengan adil. Dan janganlah } \\
\text { sekali-kali kebencianmu terhadap sesuatu } \\
\text { kaum, mendorong kamu untuk berlaku tidak } \\
\text { adil. Berlaku adillah, karena adil itu lebih } \\
\text { dekat kepada takwa. Q.S. al-Ma'idah [5]: } 8\end{array}$ \\
\hline 3 & Persatuan Indonesia & $\begin{array}{l}\text { Orang-orang beriman itu sesunggubnya } \\
\text { bersaudara. Sebab itu damaikanlah } \\
\text { (perbaikilah hubungan) antara kedua } \\
\text { saudaramu itu Q.S. al-Hujurat [49]: } 10\end{array}$ \\
\hline 4 & $\begin{array}{l}\text { Kerakyatan yang } \\
\text { dipimpin oleh hikmat } \\
\text { kebijaksanaan dalam } \\
\text { pemusyawaratan } \\
\text { perwakilan }\end{array}$ & $\begin{array}{l}\text { Bermusyawaratlah dengan mereka dalam } \\
\text { urusan itu. Kemudian apabila kamu telah } \\
\text { membulatkan tekad, maka bertawakkallah } \\
\text { kepada Allah. Q.S. Ali Imran [3]: } 159\end{array}$ \\
\hline 5 & $\begin{array}{l}\text { Keadilan sosial } \\
\text { bagi seluruh rakyat } \\
\text { Indonesia }\end{array}$ & $\begin{array}{l}\text { Sesunggubnya Allah menyuruh berlaku adil } \\
\text { dan berbuat kebajikan, memberi kepada } \\
\text { kaum kerabat Q.S. an-Nahl [16]: } 90\end{array}$ \\
\hline
\end{tabular}

Quraish Shihab menjelaskan bahwa orang-orang yang berhukum dengan menggunakan Kitab Taurat dan Kitab Injil di dalam Al-Qur'an disebut Ablul Kitäb sebanyak 31 kali, $A l$ Yahüd sebanyak 8 kali, An-Nașära sebanyak 14 kali, dan Banì Isräil sebanyak $41 \mathrm{kali}^{44}$ Ahlul Kitab atau penyebutan yang sejenis tersebut diartikan sebagai konsep yang memberikan pengakuan kepada agama di luar Islam yang memiliki kitab suci.

${ }^{43}$ Douglas E. Remagee, Pemahaman Abdurrabman Wabid Tentang Pancasila dan Penerapannya Dalam Era Paska Azaz Tunggal (Yogyakarta: LKiS, 1994).

${ }^{44}$ M. Quraish Shihab, Wawasan Al-Qur'an: Tafsir Maudhu'i atas Pelbagai Persoalan Umat (Bandung: Penerbit Mizan, 2003), hlm. 348. 
Sikap pengakuan ini bermaksud untuk memberi pengakuan hak eksistensi dalam menjalankan aturan agama masing-masing.

\section{Nasionalisme Keagamaan Sebagai Filter}

Istilah kebangsaan merupakan gambaran ciri-ciri terhadap kesatuan orang yang bersamaan asal keturunan, budaya, bahasa, dan akar sejarahnya pada suatu lokasi tertentu. Kesamaan ciri terhadap kelompok manusia sehingga dapat disebut bangsa mulai berkembang pada abad ke-18 di Eropa, dan mengalami transformasi ideologi ke dunia Islam. Penyebaran ideologi kebangsaan tersebut berkembang seiring agresi Napoleon Bonaparte ke Mesir pada Juli 1978 yang mempropaganda diri sebagai muṣlim yang taat. ${ }^{45}$ Propaganda melalui penyebaran panflet oleh 36.000 pasukan diawali dengan ungkapan "Bismillah. irrạ̣mañirraḥim” untuk menunjukkan sebagai saudara.

Strategi membangkitkan kesadaran berdasarkan kesamaan asal dan wilayah membuat sebagian umat Islam merasa bahwa nasionalisme menjadi sebab terpecahnya dunia Islam. Bagi kelompok islamisme semacam HTI, nasionalisme dianggap sebagai primordialisme dan fanatisme kebangsaan (ashabiyab) yang dihukumi haram. ${ }^{46}$ Pendapat itu menjadi pandangan politik mayoritas kelompok Islam radikalis di Indonesia. Kelompok ini berpegang teguh pada prinsip kesatuan umat yang didasarkan atas ikatan aqidah atau ideologi keislaman, bukan ikatan kebangsaan. Hal demikian mengacu pada Q.S. al-Hujurat [49]: 10, Sesunggubnya orang-orang beriman adalah bersaudara.

Perkembangan ideologi kebangsaan sesungguhnya telah dilakukan oleh Nabi Muhammad dalam proses membangun masyarakat baru kota Yatsrib. Nasionalisme modern itu ditandai dengan penyusunan konstitusi Piagam Madinah (Misaq al-Madinab) untuk mengikat seluruh masyarakat Madinah tanpa membedakan agama, suku, maupun kelas sosial yang ada. Komposisi masyarakat

${ }^{45}$ Shmuel Moreh, Napoleon in Egypt: Al-Jabarti's Chronicle of The French Occupation, 1798, Princeton: Marcus Wiener Publishing, 1993, hlm. 24-26.

${ }^{46}$ M. Kusman Sadik, "Nasionalisme dan Separatisme Haram!" (31 Maret 2013), http:/ /www.hizbut-tahrir.or.id/2013/03/31/nasionalisme-dan-separatismeharam/, diakses 10 Pebruari 2014. 
Madinah pada saat itu terdiri atas suku Auz dan Khazraj yang sebagian memeluk Islam, dan suku Quraizhah, Nadhir, dan Qaynuqa yang memeluk Yahudi. ${ }^{47}$ Piagam Madinah diberlakukan untuk seluruh suku guna membela kedaulatan kota Yatsrib yang kemudian berubah menjadi Kota Madinah.

Strategi yang dilakukan Nabi Muhammad di Madinah memiliki kesamaan dengan kehidupan kebangsaan Indonesia yang tidak menerapkan konstitusi berdasarkan hukum agama tertentu untuk seluruh suku, tetapi menerapkan konstitusi atas dasar kesepakatan bersama yang bermodalkan semangat prinsip-prinsip persamaan. Kebersamaan membela masyarakat berdasarkan aspekkewilayahan menunjukkan adanya bela negara yang dibangun oleh masyarakat Madinah.

Dalam kosakata Arab, istilah yang memiliki makna bangsa antara lain qaum dan sya'b. Kata qaum di dalam Al-Qur'an disebut sebanyak 322 kali, sebagaimana di dalam Q.S. Hud [11]: 63-84. Sedangkan kata sya'b hanya ditemukan dalam 1ayat sebagaimana pada Q.S. al-Hujurat [49]: 13: Ideologi kebangsaan atau nasionalisme jelas memiliki dasar dalam Al-Qur'an dengan adanya inklusivitas untuk saling mengenal identitas satu dengan yang lain. Tentu kebangsaan tersebut akan dijumpai adanya kebhinekaan dalam hal agama, suku, warna kulit, status sosial, dan perbedaan lain dengan dibatasi penghargaan melalui ketaqwaan, yaitu memanusiakan manusia dengan tidak saling melecehkan. Titik temu antara kebangsaan dengan keislaman dapat dilihat pada prinsip yang harus dijunjung. Berbangsa menuntut adanya persatuan masyarakat (al-ummab), perlindungan hak masyarakat (al-adalah), prinsip permusyawaratan (al-syura), dan persamaan perlakuan (al-musawah).

Nasionalisme merupakan tampilan konsep yang dibangun oleh Nabi Muhammad untuk memperhatikan kepentingan persatuan masyarakat (al-ummah al-wahidah). Atas dasar kesepakatan dan kontrak sosial,negara kota Madinah dibangun oleh generasi muslim pertama dengan menghormati kebhinekaan dalam

${ }^{47}$ Mun'im A. Sirry, Membendung Militansi Agama: Iman dan Politik dalam Masyarakat Modern (Jakarta: Erlangga, 2003), hlm. 48. 
tujuan yang sama, yaitu keadilan dan kesejahteraan. Keterbukaan masing-masing anggota masyarakat dan kesediaan para pemimpin menerima usulan merupakan model masyarakat berbangsa yang modern. Masyarakat muslim di Indonesia sejak perkembangannya sudah mengenal makna persaudaraan bukan sekadar saudara atas dasar agama (ukhuwah Islamiyah), tetapi juga persaudaraan sebangsa (ukhuwah wathaniyah), dan persaudaraan sesama manusia (ukhuwah basyariyah). Hal demikian dirumuskan oleh para pendiri bangsa dengan ikatan Pancasila.

Aksi kekerasan atasnama agama yang masih marak terjadi di Indonesia mengindikasikan bahwa sikap dan perilaku sebagian masyarakat Indonesia tidak lagi sesuai dengan prinsip-prinsip Pancasila. Masyarakat cenderung memilih aksi kekerasan atau adu kuat dalam menghadapi perbedaan. Tindakan demikian menyuburkan intoleransi beragama, pembakaran rumah ibadah, dan frustasi beragama dengan ideologisasi Islam menjadi jaringan terorisme. Masyarakat muslim Indonesia banyak yang tidak memandang bahwa Pancasila adalah prinsip beragama Islam. Dalam epistemologi hukum Islam (ushul fiqib), Pancasila sama halnya dengan al-kulliyat al-khams, yaitu prinsip dasar tujuan pemberlakuan hukum Islam. Panca prinsip hukum Islam tersebut adalah perlindungan agama ( al-nafs), perlindungan keturunan ( hifşh al-nas), perlindungan akal

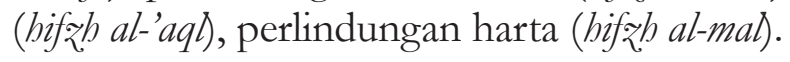

Al-kulliyat al-khams dalam konteks Indonesia sudah tercermin pada rumusan Pancasila. Sila-sila dasar negara yang merupakan asli produk budaya bangsa Indonesia, sudah memberikan perlindungan agama pada sila pertama. Perlindungan jiwa dan aspek-aspek kemanusiaan pada sila kedua. Perlindungan keturunan sebagai bentuk hak kewarganegaraan dalam sila ketiga. Perlindungan akal dan kebebasan berserikat berkumpul dalam sila keempat. Sedangkan perlindungan harta serta akses sumber ekonomi tercermin dalam sila kelima.

Pancasila merupakan pondasi norma atas hukum-hukum yang berlaku di Indonesia. Hal demikian berimplikasi pada pemberlakuan dan penerapan syariat Islam tidak boleh berlawanan 
dengan nilai-nilai Pancasila, yaitu nilai ketuhanan, kemanusiaan, perastuan, permusyawarakatan, dan keadilan. Hukum Islam ditempatkan sebagai sumber pembentukan hukum nasional yang berinteraksi dengan agama-agama lain. Pancasila sebagai mazhab berkebangsaan ditempatkan untuk meneguhkan Islam di Nusantara guna mengembangkan peradaban Indonesia dan peradaban dunia yang damai.

\section{Simpulan}

Pertemuan damai antara nasionalisme dengan agama di Indonesia berwujud dengan keberhasilan rumusan Pancasila. Karakter kebhinekaan mendapatkan posisi penghargaan yang baik guna menyinergikan ajaran Islam dengan adat istiadat atau kearifan lokal masyarakat Nusantara. Hal tersebut membentuk sistem sosial yang kemudian memetakan identitas kebangsaan itu sendiri. Formulasi Islam dan negara yang terbentuk menjadi Negara Kesatuan Republik Indonesia (NKRI).

NKRI adalah negara yang mendasarkan pola interaksi masyarakatnya menjadi terbuka, ramah, dan bersahabat dengan lingkungan budaya. Oleh karena itu Islam sebagai agama yang bersinergi dengan budaya, mengedepankan sikap jalan tengah atau moderasi (tawasut). Corak Islam di Indonesia sebagai darussalam melahirkan tegaknya Pancasila dan NKRI sebagai intisari dari ajaran Islam ablussunnah wal jama'ah. Kolaborasi antara Pancasila dan NKRI menjiwai karakteristik bangsa Indonesia yang damai, membina keberagaman, serta mampu bekerjasama dalam kebhinekaan.

Tiga pilar utama yang mendukung keberhasilan identifikasi potensi radikalisme gerakan transnasional adalah dengan menggabungkan antara pendekatan agama dengan pendekatan kebangsaan melalui kerjasama lintas sektoral. Hubungan kerjasama mesti didukung dengan pemanfaatan kekuatan struktural, dan otoritas keislaman. Sinergi kerjasama yang dilakukan antara Kemenkumham dengan BNPT serta Kementerain Agama telah menjadikan beberapa tokoh inti jaringan radikal mengakui kesalahan dan membangun rasa nasionalisme terhadap NKRI, seperti Ali Imron, Nasir Abas, dan Umar Patek. 


\section{DAFTAR PUSTAKA}

'Abid al-Jābiri, Muhammad Qadaya al-Fiker al-'Aräbi: al-Mas-alah al-Thaqäfyyah, Beirut: Markaz Dirâsah al-Wahidah al'Arābiyyah, 1994.

A. Sirry, Mun'im, Membendung Militansi Agama: Iman dan Politik dalam Masyarakat Modern, Jakarta: Erlangga, 2003.

Abegebriel, A. Maftuh, dkk (Ed), Negara Tuhan: The Thematic Encyclopedia, Yogyakarta: Pustaka Pelajar, 2003.

Abou el-Fadl, Khaled, The Great Theft: Wrestling Islam from the Extremists, New York: harperSan Fransisco, 2005.

Adisaputra, Asep, Imam Samudra Berjihad, Cet. 1, Jakarta: Grafika Indah, 2006.

an-Nabhānī, Taqiyuddīn Daulah Islam, Terj. Umar Faruq, Jakarta Selatan: HTI Press, 2009.

Ayubi, Nazih, Political Islam: Religion and Politics in the Arab World, London and New York: Routledge, 1991.

Aziz, Abdul, Chiefdom Madinah: Salab Paham Negara Islam, Jakarta: Pustaka Alvabet, 2011.

Azra, Azyumardi, Jaringan Ulama Timur Tengah dan Kepulauan Nusantara Abad XVII dan XVIII, Cet. I, Bandung: Penerbit Mizan, 1994.

Azzam, Abdullah, Runtubnya Khilafah dan Upaya Menegakkannya, Solo: Pustaka Al-Haq, 2002.

Blanchard, Christopher M, Al-Qaeda: Statements and Evolving Ideology, Congressional Research Service Report for Congress, 2005.

Feillard, Andree, NU vis-à-vis Negara: Pencarian Isi, Bentuk, dan Makna, Yogyakarta: LKiS, 1995.

Gunaratna, Rohan, Inside Al-Qaeda, Global Network of Terror, New York: Columbia University Press, 2002.

H. Purwanto, Wawan, Terorisme Ancaman Tiada Akbir: Bahaya dan Strategi Pemberantasan di Indonesia, Cet. II, Jakarta: Grafindo Khazanah Ilmu, 2004. 
Muh. Khamdan

Hitti, Philip K, History of The Arabs, London: The Macmilan Press LTD, 1974.

Ibn Hazm, Abu Muhammad, al-Iḥkeàm fì Usūul al-Aḥkām, Vol. 1, Beirut: Dār al-Afaq al-Jadīdah, 1980.

Imām al-Wāḥidi, Asbāb al-Nuqūul, Kairo: Dār al-Hadīth, 2003.

Imron, Ali, Ali Imron Sang Pengebom, Cet. 1, Jakarta: Republika, 2007.

Jurgensmayer, Mark, Terror in the Mind of God: The Global Rise of Religious Violence, California: University of California Press, 2001.

Khamdan, Muh,Bina Damai Terorisme, Kudus: Parist, 2015.

M. Lutz, James dan Brenda J. Luts, Global Terrorism, London: Routledge, 2004.

Mansur Suryanegara, Ahmad, Api Sejarah, Bandung: Grafindo Media Pratama, 2013.

Maschan Moesa, Ali, Nasionalisme Kiai: Konstruksi Sosial Berbasis Agama. Jogjakarta: LKiS, 2007.

Misrawi, Zuhairi, Al-Qur'an Kitab Toleransi: Inklusivisme, Pluralisme, dan Multikulturalisme, Jakarta: Penerbit Fitrah, 2007.

Misrawi, Zuhairi, Madinah: Kota Suci, Piagam Madinah, dan Teladan Muhammad SAW, Jakarta: Penerbit Buku Kompas, 2009.

Moreh, Shmuel, (terj), Napoleon in Egypt: Al-Jabarti's Chronicle of The French Occupation, 1798, Princeton: Marcus Wiener Publishing, 1993.

Muhammad ibn Jarīr al-Ṭabarī, Abī Ja'far, Tārikh al-Tabarì: Tärikh al-Rasūl wa al-Muluk, juz III, Kairo: Dār alMa'ārif, 1963.

Mun'im al-Hafni, Abdul, Ensiklopedia Golongan, Kelompok, Aliran, Mazhab, Partai dan Gerakan Islam, Jakarta: Grafindo, 1999.

Oentoro, Jimmy, Indonesia Satu, Indonesia Beda, Indonesia Bisa, Jakarta: Gramedia Pustaka Utama, 2010.

Onggang Parlindungan, Mangaraja, Pongkinangolngolan Sinambela 
Gelar Tuanku Rao: Teror Agama Islam Mąhab Hambali di Tanah Batak 1816-1833, Yogyakarta: LKiS, 2007.

Rabasa, Angel M The Muslim World After 9/11, Arlington: The RAND Corporation, 2004.

Ramakrishna, Kumar, "Delegitimizing Global Jihadi Ideology in Southeast Asia" Contemporary Southeast Asia, Vol. 27, No. 3 Desember 2005.

Roy, Olivier, Genealogi Islam Radikal, Yogyakarta: Genta Press, 2005.

Said Ali, As'ad, Al-Qaeda: Tinjanan Sosial-Politik, Ideologi dan Sepak Terjangnya, Jakarta: LP3ES, 2014.

Samudra, Imam, Aku Melawan Terorisme, Solo: al-Jazera, 2004.

Shihab, M. Quraish, Wawasan Al-Qur'an: Tafsir Maudhu'i atas Pelbagai Persoalan Umat, Bandung: Penerbit Mizan, 2003.

Sjarifudin TJ, Amir, Minangkabau DariDinasti IskandarZulkarnain Sampai Imam Bonjol, Jakarta: Gria Media Prima, 2014.

Umar, Nasaruddin, Deradikalisasi Pemahaman Al-Qur'an dan Hadis, Jakarta: Elex Media Komputindo, 2014.

Wahid, Abdurrahman (Ed), Ilusi Negara Islam: Ekspansi Gerakan Islam Transnasional di Indonesia, Jakarta: Gerakan Bhineka Tunggal Ika, The Wahid Institute dan Maarif Institute, 2009.

Wardlaw, Grant, Political Terrorism, New York: Cambridge University Press, 1986. 
Muh. Khamdan

Halaman ini tidak sengaja untuk dikosongkan 